\title{
PERCEPTION OF CATHOLIC LESSONS AMONG THE ELEVENTH GRADE MUSLIM STUDENTS AT SMA SANTA THERESIA JAKARTA
}

\author{
Woro Retno Kris Sejati \\ STKIP Kebangkitan Nasional Jakarta \\ woro.sejati@sampoernaeducation.net \\ Hatim Gazali \\ Sampoerna School of Education \\ gazalihatim@gmail.com
}

\begin{abstract}
The government has regulated that each student is entitled to religious education in accordance with his/her religion. However, some schools, one of which is SMA Santa Theresia (Santa Theresia Senior High School), have special regulations. Since these schools are run by Catholic foundations, they provide Catholic religious instruction to all students. Walgito (2004) reported that a person's perception will affect a person's actions. Therefore, this research aims to reveal the Muslim students' perception of the Catholic lessons they follow. This research used descriptive qualitative approach. The data were collected using interviews, observation and documentation through a process of data triangulation. The subjects selected through a purposive sampling method by considering that they are the eleventh grade students and taught by the same religious education teacher. The data were analyxed using Miles and Huberman model consisting of data reduction, data display and conclusion. The results indicated that the Muslim students have positive perception of the materials that are easy to apply in their daily lives, and also have a negative perception of the materials that have a lot of memorization and theories.
\end{abstract}

Keywords: Students' Perceptions, Muslim students, Catholic Lessons, School

\section{INTRODUCTION}

The Indonesian government requires schools in Indonesia to provide religious education to all learners. Religious education is education that provides knowledge and expects to form attitudes, personality, and skills of students in practicing religion, which is carried out at least through the subject / course in all types and levels of education. Based on the Government Regulation No 55/2007 Article 2, paragraph 2, religious education aims to help students to 
understand, appreciate and practice the values that harmonize religion with mastery of science, technology and art. Religious education is also expected to encourage the students to have the attitude of honesty, trustworthiness, discipline, hard-working, independence, competitiveness, cooperativeness, sincerity and confidence. Meanwhile, the main goal of religious education is to strengthen human's faith and fear of God Almightym making them noble and capable of maintaining peace and harmony and good relationship between religious followers (BSNP, 2006).

The implementation of religious education stipulated in Government Regulation No 55/2007, in which Article 4, paragraph 2 states that, "Each learner in an educational unit in all levels and types of education are entitled to religious education in accordance with their religion and taught by a teacher of the same religion." The article clearly states that students in any school in Indonesia are entitled to religious instruction in accordance with their religion. Muslim students should receive Islamic lessons, Christian students should receive Christian lessons, the same also applies to Buddhist, Catholic, Hindu and Confucian students.

In practice, there are schools that do not provide religious instruction according to students' religion. Some public schools only provide religious instruction to Muslim students as teachers of religion other than Islam are unavailable. Some private Catholic or Christian schools also provide religious Catholic or Christian instruction to all students. Research conducted by Mahupale (2007) on private and public schools in Bali showed that not all schools provide religious instruction according to students' religion. In fact, some schools only provide Hindu or Islamic lessons. However, there are also schools that provide general religious education, not focusing on any particular religion.

In fact, some schools under Catholic foundations in Indonesia do not provide religious instruction in accordance with the religion of their students. This is because the Catholic schools want to retain their school characteristics (Soetomo, 2009). If there are non-Catholic students attending these schools, they shall provide a statement of willingness to follow Catholic religious education to the parents who are not Catholics and asked to sign it (Darmanto in Sairin, 2006). The statement proves that non-Catholic parents know that their children will get Catholic religious instruction at school.

Besides, schools under Catholic and Christian foundations have an institution that supports them to continue to provide religious instruction in accordance with their religious characteristics. Such institution is Majelis Pendidikan Kristen (Christian Education Council) abbreviated as MPK. MPK expressed its support based on the Regulation of Education Minister of the Republic of 
Indonesia No. 71/2009 on the Establishment of Legal Organization of Basic and Secondary Education in Chapter 3 which discusses the characteristics, scope of activities and period of establishment and clause 5 which states that the distinctive feature of the school may be added by the school management. From this article it can be concluded that Catholic schools have the authority to make its own rules, including the provision of religious education regulations.

SMA Santa Theresia Jakarta is one of the schools that provides Catholic religious instruction to all students. The Catholic religious instruction, based on BNSP (2006), covers the scope of Catholic religious instruction in schools which includes four aspects, namely the church, civics, Jesus Christ and learners' personality. However, beyond the four aspects, BNSP gives authority to the school to provide additional subject of Catholicismn. In the eleventh grade, Santa Theresia senior high school students get a lesson of Catholic religion on the Church and society. The Church in the teaching material is more directed to the teachings of the specific nature of the Catholic religion. In the material on the community, it focuses on getting to know and understand the Church's relationship with the world, understand the nature of human rights and understand and appreciate life. Compared with the material in the tenth and twelfth grade, the eleventh grade materials are the most balanced in terms of thematic aspects, because there is a part of learning about the Catholic religion in particular but there are parts of the materials that deal with general knowledge.

Even though some schools do not provide religious instruction in accordance with the religion of their students, research conducted by Patimah and Kadarismana (2013) showed that parents have a positive perception of their children's participation in Catholic religious instruction. Positive perception here means parents are not concerned about the participation of students in Catholic religious instruction. Parents assume that the Catholic religious education is similar to civics or character education for their children. Parents also stated that the participation of children in Catholic religious instruction at school does not affect their belief in their own religion. For parents, they can offer religious education at home or at other religious institutions. They are actually proud of their children becoming more disciplined after the entry of the Catholic school. In fact, Ernawati (2010) who did research on the religiosity of Muslim students in Kolose De Brito Catholic school Yogyakarta, showed that despite the intensity of worship is relatively low and the knowledge of religion is less, the students have good social behavior, and have a fear of God.

The research report by the DIAN Interfedei in 2004-2006 states that the Catholic religious education for non-Catholic students is not considered useful 
to a student's life. They think that it is better to provide spiritual education that will help them get the religious knowledge that is relevant to their religion. Regardless to what is revealed in the report of DIAN Interfedei institution, the important thing is state of students who receive religious instruction inconsistent with their religion. Romo Mangun (in Prasetya, et al., 2009) revealed that the most important thing is not the students receiving religious instruction in accordance with their religion, but it is how students reflect on the religious experiences they get.

Rachmat (2009) stated that a person's behavior is influenced by perception. In the process of its formation, perception is affcted by the environment (Walgito, 2004). Perception itself is a process a person experiences objects, events or relationships obtained by concluding information and interpreting the message. In this context, the Muslim students' experience is receiving the instruction of the Catholic religion. So, the experience will influence the perception of the Muslim students. Perceptions are formed too, which will affect them in their daily actions.

\section{OVERVIEW OF SMA SANTA THERESIA JAKARTA}

SMA Santa Theresia is a School of Santa Ursula, located on Jalan Pos No. 2 Central Jakarta. In the 2013-2014 academic year, SMA Santa Theresia had 39 teachers, 7 staff of administration and library, 1 computer technician and 7 school janitors. The total number of students of Santa Teresa was 474 . The 474 students were divided into 17 classes and again divided into three levels, namely the tenth, eleventh and twelfth grades. Each grade was divided into two departments of science and social studies. There were 155 students in the tenth grade (Class X), 163 in the eleventh grade (Class XI) and 156 in the twelfth grade (Class XII). The majority of students at SMA Santa Theresia are Catholics. Muslim students at SMA Santa Theresia were only 15 or 3.16\%. Of the total 15 Muslim students, two are in class XII, 4 in class XI and 9 in class X. Muslim Students at SMA Santa Theresia are divided into three classes, namely class XI IPS I, XI IPS II and XI IPA I.

The four Muslim students at SMA Santa Theresia are the subjects of this research, three of them from social studies class and one from science class. The four subjects are Badriah, Munaroh, Dian and Lukman. Badriah is female and Muslim since birth. Both her parents are Muslim, but his father was a convert. Her father converted to Islam after marrying her mother. Before getting married, her father was Christian and had two children who now live in America. She is the first child of 3 brothers. She has been a student at Santa Theresia since kindergarten. Munaroh is female and Muslim since 
birth. Both her parents embraced Islam since childhood. In her family, she is the only child. She has been at Santa Theresia school since the tenth grade of high school. Before SMA Santa Theresia, she had studied at the Singapore International School in Medan. She went to SD and SMP Negeri 1 Palembang.

Dian is female and Muslim since birth. Both her parents embraced Islam since birth as well. she is the first child of 3. She has been a student at Santa Theresia since high school grade ten. Before that, she went to school at Santa Maria Bandung. Lukman is male and Muslim since birth. He comes from a family with different religions, his mother converted to Islam and his father embraces Catholicism. Lukman is the first child of two and has been at Santa Theresia since kindergarten.

\section{MUSLIMS STUDENTS' PERCEPTIONS OF CATHOLIC RELIGIOUS LESSONS}

The material of the Church and the World is given in the 2nd semester at SMA Santa Theresia. This material discusses the relation between the Church and the world, and the Church's role in dealing with world's problems. In the textbook, the purpose of learning in is to enable students to put themselves in the positions of others in this world. In studying this material, students feel that there are sub-chapters that are easy and some that are hard to learn. Subchapters that are difficult to learn deal with Social Doctrine of the Church. According to Muslim students, this section is difficult to study because the material is a lot, complex and using foreign terms that are difficult to remember. In the Social Doctrine of the Church materials, the most difficult is one that discusses the Encyclical. In the material, students are asked to write a paper containing the letters made by any Pope during his reign along with examples of its application in the present life and the relationship with the time the letter was made. Based on the interview, some Muslim students reported that they did not like a lot of rote materials so they did not like the Encyclical material. Only one Muslim student who claimed that she did not have a problem with memorizing a lot, because she is used to memorizing. However, all the Muslim students stated that they felt too lazy to memorize the encyclical materials because these materials are of no use to them. According to them, the lessons are just as common knowledge as history or sociology.

Meanwhile, the material that is easy to learn in the chapter of the Church and the world is a lesson that discusses the role and relationship between the church And the world. Muslim students revealed that the material can be implemented in real life so it is easier to understand.

In the material of Human Rights and Human Life Appreciation, students learn 
about how to value human life given by God. The materials being studied include knowledge about abortion, suicide, drugs, HIV and respect of fellow human beings.

Of all the materials that have been learned from the 1st semester, students find it most convenient and interested in learning about these two chapters. These materials have no definite theories that must be learned and memorized. The discussion on this matter is also related to the daily life of students, so that more students benefit from the instruction.

According to the students, this material provides knowledge and makes them aware of the reason why they should not use drugs and promiscuity. By knowing these reasons, it makes them feel the need to be more careful in relationships. In addition, students also realize the importance of respecting their peers and knowing the impact of being disrespectful to friends. Students revealed that the material of respect for human life isl for their reflection.

Bible verses and Documents of Vatican II are among the reference materials that are often used in studying Catholicism. Sources from the Scriptures must come from the Bible, while the issue of the Second Vatican Council document obtained from the teachers. Students are required to take notes of the documents of Vatican II. These notes that will be used as a learning resource when they review the material that discusses the documents of Vatican II.

Muslim students at SMA Santa Theresia revealed that they had difficulty in learning the material containing Bible verses and the documents of Vatican Council II. Materials related to the documents of Vatican II make students confused as the names of documents are written in a foreign language and so are many other existing documents. This difficulty is caused by their incomprehension of the verses in the Bible and they are also confused with the words that are written in verses. Students claim that some verses of the Bible are written in a language that they barely understand and seek its implementation in everyday life. Students also are confused with the names of the verses and the chapters are so difficult to memorize and they often get mixed up in memorizing the story and the characters in the Bible verses.

Difficulties experienced by these students in fact causes laziness to learn the Bible verses. However, laziness felt by some students is not only based on the difficulty, but also by the fact that they are Muslim students who must learn the verses in the scriptures of other religion.

Badriah who comes from a Muslim family said that she felt bad to learn about the materials. She also felt sad that she had to learn about some other religion. She was afraid she would be interested in Catholicism when she learned about 
the Bible verses. Although she does not know a lot about her religion, she remains confident with her religion and does not want to convert to another religion.

Being reluctant to learn the Bible verses is also felt by Munaroh. She was born and raised in a Muslim family. Studying the Scriptures are things that she would always avoid. When there are assignments or questions about a Bible verse, she often asks a friend. She stated that he did not want to read verses contained in other holy books. She is a Muslim, so the scripture she should be read and study is only the Qur'an. She felt uneasy to follow the Catholic religious lessons as she should read the Bible. Santa Teresa religious teachers stated that they are aware of the existence of Muslim students in their class and understand if they do not join activities typical to the Catholic religion.

Dian had a different feeling from Badriah. Dian reported that she was not bothered by the situation that she had to learn Bible verses in Catholic religious instruction. She revealed that she actually took the lessons from Bible verses and stories about biblical figures by considering them to be the fables of the Middle East.

Feeling indifferent in learning Bible verses is shared by Lukman. He grew up in different environments as his mother and sister are Muslims while his father Catholic. Lukman was not depressed at all when studying the material with Bible verses. According to him, the material is just general knowledge. Nevertheless, Lukman remained steadfast in Islam and not at all was interested in learning more or converting to Catholicism. He is always reminded by her mother about his religion.

Based on observations made during which the Muslim students were attending religious instruction in the classroom, it appears that Badriah and Dian listened attentively to the Catholic religion lessons. They both paid attention when a friend explained about the material covered.

Meanwhile, Lukman and Munaroh do not pay full attention when Catholic religious instruction is in progress. Lukman sometimes tells his friends some joke during the lesson and sometimes he feels sleepy when the teacher is giving explanation. However, he remains actively involved when a friend asks for some people to come forward to play a role.

In the interview, Lukman also admited that sometimes he feels bored to follow religious instruction, not because the material but because of the learning system, (interviewed on April 28, 2013) "I just sleep, then listen to the presentation then if I'm bored, I have a chat. Yeah I'm juat bored with the teacher ". Munaroh also seems to lazily follow religious instruction in the 
classroom. At the beginning she was listening to the presentation carefully but, over time she looked bored, and looked down and closed her eyes.

\section{DIFFERENT PERCEPTION AMONG STUDENTS}

Muslim students have different perceptions of their participation in Catholic religious instruction. Munaroh revealed that she had no problem to follow Catholic religious instruction at SMA Santa Theresia. According to her, the subject of Catholic religion taught is general information about Catholic teachings. The following are excerpts of interviews with Munaroh, "The lesson is not only about Catholicism. There are other things like manners." Additionally, Munaroh revealed that she considers the Catholic religious lesson as civics education which is mandatory for students in Catholic schools.

Before studyin at SMA Santa Theresia, Munaroh was a student at the Singapore International School (SIS) in Medan and at SMPN 1 Palembang. While studying at SIS Medan, she did not receive religious instruction, and at SMPN 1 Medan she received Islamic lessons.

Munaroh revealed that the Catholic religious lesson at SMA Santa Theresia is easier than Islamic religious education she had learned in junior high. Munaroh said, "Islam has more difficult materials, crazy. Arabic, Salat. Anyway it is difficult." She thinks that lessons in Islam are more difficult to understand because of the use of Arabic. According to her, the Catholic religious instruction is not difficult really, because the Indonesian language is used”.

Munaroh also revealed that a non-Catholic individual will not be suddenly attracted to Catholicism and then convert when studying the Catholic religion at school. According to her, the subject of Catholic religion given at school will not be enough for a person to know what the Catholic religion is all about and then to get attracted to it.

Overall following the subject of the Catholic religion, as Munaroh reported, had no difficulty. She stated that there is much to memorize. However, she had no difficulty in memorizing religious subject because basically she prefers memorizing to counting or understanding a lesson.

Unlike Munaroh, Badriah is very unhappy with the material that requires memorization. She also has difficulty in studying the materials of the Catholic religion. Although she does not like to memorize, in the Catholic religious instruction she chooses the method of learning by memorizing. In fact, she realizes that there are other ways to learn the material of Catholicism which is by understanding the lesson. However, Badriah does not intend to 
really understand the lessons of the Catholic religion. The reason is because Catholicism is not her religion.

Badriah has received Catholic religious instruction since kindergarten. She is aware that Catholic religious instruction does not always lead to Catholic teaching. However, she is still afraid of being attracted to the teachings of the Catholic religion during the instruction. She revealed, "The lessons are not really interesting. It's not my religion. So, I'm here just to learn, after that I will forget it".

Due to the fear of conversion, Badriah chooses to study Catholic religion by simply memorizing material alone and forgetting it afterwards. She begins to feel discomfort studying the Catholic religion since entering high school, where she studies more difficult subjects and is increasingly aware that she is not learning her own religion.

Although Badriah revealed that she does not want to seek to understand the religious study material, in the classroom, she remains serious to follow and listen to the instruction. She also remains active in the duty when her group is chosen as for the worship activities. She admitted that she always chooses roles that do not require too much involvement in Catholic worship when leading the prayer. It is true, as observations show that it appears that Badriah served as the prayer reader only. Based on the interview, she said that the prayer is simply reading the sermon and not her initiative. The community prayer is the work of a friend and some she found on the internet.

\section{PARTICIPATION IN THE CATHOLIC LESSONS}

Badriah reported that, "(I) feel bad about learning the religion of other people, while you are not practicing your own, sometimes I feel sad ". Badriah admitted that at this time she did not learn the Islamic religion. She had Islamic lessons for a year, namely when she was in the 6th grade. After that, she has never again studied Islam, which is why she felt sad when she had to learn the Islamic lessons.

Badriah's sadness for not studying her own religion but instead studying another is also shared by Dian. Dian felt that the knowledge of her own religion is still lacking. This is because she never formally studied Islam. At home, she lived with her family who are all Muslims. However, her mother prohibits her from taking Qur'anic lessons at any place. This is because her mother was worried that she would become fanatic or even worse a terrorist. Therefore, her mother's fear has led Dian to receive no Islamic lessons.

Badriah has been in Catholic schools since kindergarten so the religious lesson 
she received from childhood to date is the Catholic religion. Dian reported that she likes to learn the subject of the Catholic religion in primary and secondary education. In the discussion of the material, it is mainly about the story of the characters that exist in the Bible. According to the story of these characters set an example for her life. Dian recounted that she likes studying a person's biography. Studying the figures in the Bible, one of whom is Jesus, to Dian is similar to studying the person's biography.

Starting at the high school level, Dian was not so keen on the subject of the Catholic religion. She revealed that at high school, the lessons have started to discuss the structure of the church and required memorization. Meanwhile, She is not the type of person who likes to memorize.

Regarding the participation in the lessons of the Catholic religion, Dian said that she did not feel depressed or uncomfortable about having to learn the religion is not hers. She realized that studying the subject of the Catholic religion is a consequence because she went to a Catholic school. According to her, all religions teach the same things. Therefore, she just took the positive values of the subject of religion she is studying. However, in certain respects, Dian felt confused because of the teachings of the Catholic religion are different to those of her religion.

"What can I say? Sometimes, I think there are things that are contrary to the Islamic religion so I feel like a bit uncomfortable. The argument of what is allowed or prohibited for example, in Islam it is clear without using your own argument. Both the Bible and the Qur'an's have been re-written by humans, certainly there is an effect on them. So in fact if the prohibition may be related to health reasons. Then talking about Jesus, well I don't understand .. haha ".

Responding to the confusion itself, Dian often asked her mom or friends, however, her friends gave a negative response to her question. Negative response means that people who refuse to talk to her about the problems she encountered, or responded with jokes. Such response has caused her to refrain from asking more questions about things that confuse her. Currently, Dian chose to remain silent and not to question things that confuse her.

The observation in the classroom showed that Dian was serious in following the religion lessons. When her friends explained something, she would listen and when his teacher asked to take notes, she did it as instructed. She was also actively involved in the group discussion or to provide questions to the group presentation.

Unlike Dian who was serious in following the lesson of the Catholic religion, Lukman often had a chat with friends sitting next to him during class. He also 
sometimes teased him friend giving a presentation. In a group discussion in class, he was mostly silent and took any suggestions from his friends.

In the interviews, Lukman said that he was often bored during religious instruction. He felt bored not because he had to study the Catholic religion but because he thought the class was boring. He said that the subject of religion contains material similar to that of Sociology, History and Civic Education which all have theories to memorize. In connection with his participation in religious subject, Lukman was indifferent. The following are excerpts of interviews with him, "My feeling is just OK, not like other Muslims taking it seriously, well it doesn't affect me. There's no pressure at all “.

\section{MUSLIM STUDENT RELIGIOUS ACTIVITIES}

Based on the interviews, Muslim students' at a Catholic school are unable to perform their duties as Muslims. Muslim students in Catholic schools stated that they are rarely able to perform the obligation of Prayer five times a day when when they are at school. They have problem looking for a place for Salat and is afraid to ask for permission from the teacher.

Based on information obtained from the Catholic religion teachers, all teachers at SMA Santa Theresia have always given Muslim students permission to establish prayer, however, they have to bear the risk of leaving school hours. The risk is to miss class or to have reduced time during a test. Besides being unable to perform the five daily prayers, Muslim students also said that they could not recite or read the Quran in Arabic and did not know the rules in Islam.

\section{GRADES OF RELIGIOUS LESSON FOR MUSLIM STUDENTS}

Based on interviews and documents obtained from the school, Muslim students' grades in religious lessons are not bad. The four Muslim students revealed that the grades of religious lesson in the report book was never below KKM (minimum mastery criteria). Lukman's grade in the first Mid Semester exam was poor because he did not learn the material. Badriah revealed that her grade was 81 and the figure is higher than some of her classmates who are Catholics. Munaroh and Dian also said that they are above the KKM.

Badriah, Dian and Munaroh said that they had no difficulty in working on the questions in midterm or final exams. Usually Muslim students will memorize on the eve before the exam. Lukman is aware that his grade is low because he did not study seriously.

In the exam of Catholic religion lessons, the questions are a mixture of multiple 
choice and description. In the test there are several multiple choice questions which are related to the Bible verses or Vatican Council documents, but they feel no need to memorize it because it did not affect their grades. Muslim students admitted to answering random questions about Scripture or Vatikan Council documents.

\section{CHALLENGES OF LEARNING OTHER RELIGIONS}

The results findings show that some of the subjects had trouble following some of the subject material of the Catholic religion because it is hard to find its implementation. Implementation of the material is indeed easier for students to learn and make students more interested in learning. This is supported by Farmer (1999) who argued that by knowing the implementation in real life, students will be more aware of the reason why they need study science at school.

Catholic religious instruction in class XI is the most religious subjects compared with the thematic material of class X and XII. Students learn about typical and common teachings of Catholicism. Students reported that the common material is easier to learn because they consider it more useful and can be used as a reflection.

The lesson of Catholic religion, which contains theories or the hierarchy of the Catholic religion and about the Bible verses as well as the Vatican Council documents are also considered difficult by Muslim students and they think there is no benefit for them. This shows that they have no real intrinsic motivation for them to learn. Intrinsic motivation is the motivation that comes from the students (Djamarah, 2008). Students learn about Catholicism associated with materials typical of the Catholic by extrinsic motivation is motivation that comes from outside. Extrinsic motivation in this instance is the fact that students attend classes only because of a duty or value.

Djamarah (2008) revealed that essentially primary and intrinsic motivation is more important than extrinsic motivation. Students who have intrinsic motivation will be more enthusiastic and not easily affected by outside influences. Based on the research results, there is one Muslim student who had intrinsic motivation to learn the lessons of the Catholic religion. The student said that he was pleased with some of the material in the Catholic religion because it can add to his knowledge. In the everyday life, Dian channels the desire to watch BBC or Discovery Channel. In contrast to Dian who has intrinsic motivation in studying Catholicism, Badriah has strong extrinsic motivation in following the lesson of the Catholic religion. She revealed that 
her aim to seriously follow the Catholic religion lesson is in order to get good grades or at least on the KKM. Intrinsic motivation is not seen in her, because she was in fact sad to have to follow religious instruction inconsistent with her religion.

Lukman and Munaroh have another view of the religious instruction, in which they have less intrinsic and extrinsic motivation. They just follow the Catholic religion classes because it is required at school. They are less concerned with the grades or the knowledge that they will get. What is important for them is to get a grade above the KKM. Badriah expressed negative perception in the form of feelings of sadness when following the lessons of the Catholic religion. It is caused by factors that influence the perception of needs (Rachmat, 2009). Badriah felt no need for the Catholic religion lessons in her life and she is more in need of Islamic religious instruction in accordance with her religion while at school she would still be required to learn the Catholic religion in which she felt sad. Sadness she experienced is not just because of necessity, but also because of the experience factor. According to Rachmat (2009), the experience is indeed one of the factors that affects the perception. Badriah feels sad because she has never studied Islam in depth while she is in fact required to study the Catholic religion. This causes doubt and fear in her when she becomes interested in the Catholic religion.

Unlike the others, Munaroh studied Islam in previous schools and had more positive perceptions about attending religious instruction. The Catholic religion lessons she is learning now is not about the doctrine of Catholicism. She added that what they learn is not going to make them want to learn more deeply about the Catholic religion. According to her, Islamic religious instruction given in public schools is much deeper than the Catholic religion lessons she gets now. Munaroh does have an insight into Islamic education than the other three research subjects. Basically, she comes from a Muslim family. She gained knowledge of Islam from her Qur'an teacher and previous schools.

Brofenbrenner (in Santrock, 2007) revealed that the environment will affect the way people think. This opinion is proved by the varied perceptions of students in response to their religion. Students who come from Muslim families provide guidance and a reminder to children to be more devout and make Al-Quran the sole basis for their life. It seems that in the end the child does not want to open and read the Bible verses. Meanwhile, students from Muslim converts are less strict in terms of religion, even their families still keep the Bible. Badriah said that her mother always warned her not to take Catholic religious instruction seriously. The result is that students are 
becoming sad every time they attend the Catholic religion classes. While Dian is always advised by his grandfather that all religions are the same. This affects the way she considers studying Catholicism. However, the problem for her is when she gets different story in Islam and Catholicism.

While Lukman comes from a family with different religions, Muslim-Catholic, his father is Muslim and his mother Catholic. His family is more tolerant. For example, his father respects his wife not eating pork at home while his wife and children let the father to perform worship each week. In the process of education, the mother actively participates in the religious education of children, so the children follow the religion of the mother. Lukman said that he had attended his father's mass at church, but because his mother forbade, he never went there anymore. His mother's doctrine indeed lingered in the memory of the child. It is evident that this child will remain loyal to the religion of Islam as a mandate and the doctrine of the mother.

When viewed from the family of research subjects, most of the research subjects are closer to the figure of the mother so that they are also likely to follow the advice of their mother. Paloutzian (in Santrock, 2006) argued that the indoctrination of the surrounding environment will affect a person's beliefs. It is evident that in reality the indoctrination of the mother affects students' religious beliefs.

According to Fowler's religious stage of development (in Santrock, 2006), the subject of research is currently in the stage of synthesis-conventional faith, which is the stage where someone is likely to adhere to the religious beliefs of people and have not been able to adequately analyze alternative ideology. The results showed that the SMA Santa Theresia Muslim students have been in this stage, where they still adhere to the teachings of their religion even though they receive instruction on other religion.

Glock and Stark (1996) argued that religiosity of a person can be divided into five dimensions i.e. belief, religious practices, appreciation, experience and knowledge. Broadly speaking, judging from the belief dimension of Muslim students in Catholic schools, it is still good because they still trust and believe in the religion of Islam. Although they are still teenagers whose thinking is still unstable, the dimensions of their religious beliefs never changed. However in terms of worship practices, they are still lacking because the research subjects admitted that they have not been able to establish prayer five times a day because of the unavailability of facilities of worship for them at school. Nevertheless, the Muslim students still perform fasting. Judging from the dimensions of appreciation and experience, the Muslim students still fear for violating the commands contained in the teachings of Islam. However, in the 
dimension of knowledge, they are still lacking due to the absence of people or institutions that support and help to provide knowledge about the religion of Islam to them.

Muslim students who get lessons of Catholic religion have a positive perception of their participation in Catholic religious instruction. They understand and appreciate their school policies despite losing their right to receive religious instruction in accordance with their religion as regulated in the 2003 Education Law.

Based on the information obtained from one of the religious teachers, SMA Santa Theresia had experienced confusion about religious education to instruct at school. They realized that they did not follow the government regulations, but they also recognize they objected to giving non-Catholic religious instruction. For them it would not be in accordance with the mission of the school stating that they wanted to prepare Indonesian human resources who are critical, innovative and creative in science and faith according to the spirit of St. Angela. The missions of the school apply to all students. In the research conducted by DIAN Interfedei, it is stated that the implementation of religious education can be used as an alternative to religious education for the Catholic school. However, Catholic school teachers stated that religious education does not become official curriculum for the government. So SMA Santa Theresia has doubt about the implementation of religious education and chooses to provide Catholic religious instruction to all students.

\section{CONCLUSION}

The results of the research showed that the Muslim students' perception of the subject of the Catholic religion at SMA Santa Theresia, especially regarding the material of the Church and the World is quite negative. Students find it difficult to study this material because there is too much to memorize in a foreign language. The students' perception of the material on the role and the church's relationship with the world tends to be positive. Muslim students reported that this lesson is easier for a broader study material and every discussion is easier to find implementation in their daily lives. Muslim students' perception of the material of Human Rights and Human Life Award. Muslim students' perceptions on this matter positively, they find it easy to learn the material. They are interested in studying this material because almost all materials directly related to the implementation of real-life and can be used as a reflection of their lives. Muslim students' perceptions about the material Scriptures and the documents of Vatican Council. Muslim students have a negative perception on materials associated with Bible verses and the 
documents of Vatican Council. For them, this material is confusing because the language used is difficult to understand and many verses and documents that must be memorized.

In addition, the perception of Muslim students who attend classes in the Catholic religion in general is positive. They refer to the study of the Catholic religion merely as ordinary subject such as civics education. However, basically the students have a different perception regarding the necessity of their study of the Catholic religion. New students in a Catholic school do not mind attending the Catholic religion class because they are not affected by the teachings of the Catholic religion. Students who come from a family of Muslim converts, one of them expressed his concern following the Catholic lessons while students who come from Muslim-Catholic family reported that he was not burdened by the Catholic religion lessons because for him all religions essentially are the same. Muslim student religious activities when seen from the dimensions of belief by Glock and Stark (1996) are still good because they still believe in the Islamic religion; Worship practices are still lacking because the research subjects admitted that they had not been able to establish prayer five times a day due to the unavailability of facilities of worship for them in school; from the dimensions of appreciation and experience, the Muslim students still fear for violating the commands contained in the teachings of Islam. However, in the dimension of knowledge, they are still lacking due to the absence of people or institutions that support and help to provide knowledge about the religion of Islam to them.

From these results, this research has several methodological and practical suggestions for conducting similar studies in the future. The school especially Vice Principal for Curriculum and Catholic Religious Studies as well as teachers can consider Muslim students' perception of the subject of the Catholic religion. Methodologically, there should be expansion of research subjects as in this study the subjects of research were only students of class XI where they shared similar experience in attending the Catholic religious class in high school. Future research can be conducted using research subjects with a wide range of experience which will generate more vried data.

\section{REFERENCES}

Laelasari, C. (2013). Manajemen penyelenggara pendidikan inklusif sekolah X Di Kota Bandung. Thesis, Program Studi Pendidikan Kebutuhan Khusus, Universitas Pendidikan Indonesia. 
Darmin, S. \& Darwis. (2003). Metode penelitian sistem kebidanan: prosedur, kebijakan dan etik. Jakarta: EGC.

Djamarah, S. B. (2008). Psikologi belajar. Jakarta: Rineka Cipta.

Ernawati, N. (2010). Tentang religiusitas siswa Muslim di sekolah Katolik Kolose De Brito Yogyakarta. Dinduh pada 17 April 2013 dari http://digilib.uin-suka.ac.id/5108/.

Farmer, L. S. J. (1999). Cooperative learning activities in the library media center. United Stated: Teacher Idea Press.

Glock, C.Y.\& Stark, R. (1996). Religion and society in tension. Chicago: Rand McNelly and Company.

Jogiyanto. (2008). Metode penelitian sistem informasi, halaman 71-78. Yogyakarta: Andi Offset.

Mahupale, J. E., Abdullah, I. (2007). Pendidikan agama berwawasan pluralis: Analisa hubungan dan pengaruh pendidikan agama terhadap pandangan sikap dan perilaku para siswa SMU di Denpasar Bali. Diunduh pada 03 Maret 2015 dari http://repository.ugm.ac.id/75114/.

Nurfuadah, R. N. (2013, Januari 28). Dipetik Oktober 12, 2013, dari okezone: http://news.okezone.com/read/2013/01/28/373/752891/pemaksaan-pelajaran-agama-bukti-diskriminasi-sidiknas

Patimah, I. \& Kadarismana, Y. (2013). Persepsi orangtua siswa Muslim terhadap keikutsertaan anaknya belajar di Sekolah Dasar Katolik Santa Maria Pekanbaru. Diunduh pada 17 April 2013 dari http://103.10.169.96/ handle/123456789/2511

Pawito.(2007). Penelitian komunikasi kualitatif. Yogyakarta: PT LKIS Pelangi Aksara.

Permatasari, Y. (2013). Religiusitas siswa Muslim di Kanisius Tegalmulyo Yogyakarta. Diunduh pada 13 April 2014 dari http://digilib.uin-suka. ac.id/9651/1/BAB\%20I,\%20IV,\%20DAFTAR\%20PUSTAKA.pdf.

Rakhmat, J.(2009). Psikologi komunikasi. Bandung: PT Remaja Rosdakarya.

Razak, N. (1989). Dienul Islam. Bandung: al-mMaarik.

Sairin, W.(2006) Identitas dan ciri khas pendidikan Kristen di Indonesia antara konseptual dan operasional. Jakarta: Gunung Mulia.

Santrock, J. W. (2007). Adolescence (B. Widyasinta. Terj.) (ed. ke-11). Jakarta, Indonesia: Erlangga. (Karya asli diterbitkan 2007)

Soetomo, G. (2009). Built to last. Bogor: Grafika Mardi Yuana.

Sugiyono. (2012). Metode penelitian kuantitatif, kualitatif, dan kombinasi (mixed methods). Bandung: alfabeta.

Sunaryo. (2004). Psikologi untuk keperawatan. Jakarta: EGC.

Walgito, B. 2004. Pengantar psikologi umum. Yogyakarta: Andi Offset.

Prasetya, dkk. (2009). Pendidikan Religiositas -Gagasan, Isi dan pelaksa- 
naannya.Yogyakarta: Percetakan Kanisius Yogyakarta. Dilihat pada 11 Januari 2015 pada https://books.google.co.id/books?id=F9vTY8IDK9QC\&pg=PA15\&dq=romo+mangun+tentang + fungsi + pendidikan +agama\&hl=en\&sa $=$ X\&ei=-gX5VMHsM82zuATGmIEo\&redir_es$\mathrm{c}=\mathrm{y} \# \mathrm{v}=$ onepage $\& \mathrm{q} \& \mathrm{f}=$ false.

Tanuwidjaya, N. (2013). Persepsi kepala sekolah, guru dan siswa terhadap mata pelajaran Bimbingan Konseling di SMA 'Regina Pacis' Jakarta. Skripsi pada STKIP-Kebangkitan Nasional.Jakarta: tidak diterbitkan. -(2004-2006). Laporan Penelitian DIAN Interfedei: Problematika Pendidikan Agama di Indonesia 